\title{
Impact of Habitat Complexity on Body Size of Two Spider Species, Alopecosa cuneata and A. pulverulenta (Araneae, Lycosidae), in River Valley Grasslands
}

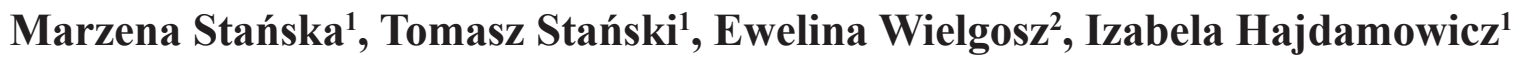 \\ ${ }^{1}$ Siedlce University of Natural Sciences and Humanities, Faculty of Natural Science, \\ Department of Zoology, B. Prusa 12, 08-110 Siedlce, Poland \\ ${ }^{2}$ Warszawska 80A, 21-400 Łuków, Poland
}

Received: 9 April 2017

Accepted: 11 July 2017

\begin{abstract}
Many studies have shown that vegetation structure and habitat complexity affect taxonomic composition, functional diversity, and the number of individuals in spider assemblages. These factors also affect spider body size, but mechanisms responsible for that are still not well understood. In our research, we examined the relationship between the body size of spiders from two species - Alopecosa cuneata and A. pulverulenta - and environmental factors such as habitat type and habitat complexity. Our research was conducted in the Bug River Valley on 12 plots covering three types of habitats: mesic meadow, sandy grassland, and xerothermic grassland. Spiders were collected in 2007-08 from April to mid-November using pitfall traps. In total we measured 334 males and 168 females of Alopecosa cuneata and 315 males and 104 females of $A$. pulverulenta. The generalized linear mixed model revealed that individuals of Alopecosa cuneata as well as A. pulverulenta reached larger sizes in more complex vegetation, whereas the habitat type did not affect the spider body size. One of the likely mechanisms responsible for a larger body size in more complex habitats is predator pressure. Birds as the main predators of spiders, being selective in their choice of prey, may collect larger spiders with higher intensity than smaller ones. We suggest that more complex habitats with dense vegetation provide better shelter for large spiders, which allows them to avoid predators. Our results indicate that habitat complexity may be an important determinant of body size distribution in spider assemblages.
\end{abstract}

Keywords: spider body length, epigeic spiders, vegetation complexity, body size distribution

*e-mail: marzena.stanska@uph.edu.pl 


\section{Introduction}

Body size is correlated with many physiological and ecological processes as well as organism's traits, e.g., metabolic rate [1], life duration [2], predation [3], parasitism [4], and competition [5]. Current knowledge of mechanisms affecting the body size distribution is based mainly on studies involving vertebrates [6-9], while researches on invertebrates are still rare, although more frequent during last years [10-15]. Many of these studies analysed body size patterns of a particular group of invertebrates on a large geographical scale like a continent [10, 12-14], whereas knowledge about mechanisms affecting body size distribution on a local scale are still limited [11, 16-17].

Spiders are an excellent group of organisms to study mechanisms responsible for body size distribution, both on large geographical and local scales. They occur in large numbers in most habitats and they are very sensitive to habitat structure and microclimatic conditions [18]. Many studies have shown that complexity and structure of habitat (which often comes down to vegetation structure and density) had a significant influence on the abundance, species richness, and distribution of spiders [19-23]. Despite the great number of research on spiderhabitat interactions, only limited studies have included body size. On a large geographical scale, i.e., Europe, Entling et al. (2010) showed that the mean body size of spider assemblages increased from cool and moist to warm and dry environments [12]. Research by Drapela et al. (2011) revealed that landscape structure (e.g., distance to the nearest woody area) affected the body size of Pardosa agrestis - one of the most abundant spiders in arable fields [24]. Gibb et al. (2015) studied the impact of climate and habitat factors on morphological traits of foliage-living spiders in grassland in Australia [25]. They found a relationship between some morphological traits of spiders (e.g., body length, fang length, asymmetry) and environmental factors (elevation, latitude, longitude, annual mean temperature). Moreover, some authors have conducted experiments consisting of the manipulation of habitat complexity and proved that in a more complex habitat (i.e., with more dense vegetation), spiders are larger [26-27]. However, the mechanisms responsible for the increase in spider body size in more dense and complex habitats are poorly understood. One of the reasons for this phenomenon is the pressure of predators. Spiders are particularly exposed to predation by birds [28], who while searching for prey usually choose more conspicuous (i.e., larger) spiders [29-31].

In this paper, we analysed the relationships between the body size of two spider species and environmental factors such as habitat complexity and the type of habitat in the Bug River Valley in eastern Poland. According to McCoy and Bell (1991), habitat complexity can be defined as absolute abundance (per unit area or per unit volume) of individual structural components, but precise definition depends on a spatial scale at which it is examined [32]. In our research, habitat complexity reflected the degree of surface cover by vegetation in different height classes. We chose two model species belonging to the Lycosidae family: Alopecosa cuneata (Clerck, 1757) and $A$. pulverulenta (Clerck, 1757). Both analysed species are common in Europe and Poland and can be found mainly in open areas [33-35]. Alopecosa cuneata in central Europe inhabits mostly oligotrophic grasslands, fresh meadows, forest edges, vineyards, and ruderal areas [35]. A. pulverulenta has a wider habitat amplitude than A. cuneata and occurs on oligotrophic grasslands, fresh and moist meadows, raised bogs, forest edges, and coastal habitats [35-36]. None of the two species builds a hunting web. Instead, they actively hunt on the ground.

We proposed a hypothesis that body size of the studied spider individuals increases together with increasing habitat complexity in line with the results obtained by the above-mentioned authors [26-27]. We also expected a difference in the body size of spiders between the analysed habitats (mesic meadow, sandy grassland, and xerothermic grassland).

\section{Material and Methods}

\section{Study Sites}

The research was conducted in the Bug River Valley (a large lowland river in Eastern Poland, 52 $41^{\prime} 32.14^{\prime \prime} \mathrm{N}$, $\left.21^{\circ} 52^{\prime} 57.07^{\prime \prime} \mathrm{E}, \quad 52^{\circ} 16^{\prime} 53.15^{\prime \prime} \mathrm{N}, \quad 23^{\circ} 08^{\prime} 35.44^{\prime \prime} \mathrm{E}\right)$ at 12 study plots located near the villages of Mogielnica, Morzyczyn, Płatkownica, Zabuże, and Gnojno. Our research covered three types of habitats in the valley: mesic meadow (four plots), sandy grassland (four plots), and xerothermic grassland (four plots). Mesic meadows (Poo-Festucetum) developed in the upper alluvial terrace were located in Mogielnica, Morzyczyn, Płatkownica, and Zabuże. Xerothermic grasslands occurred on the slopes at the edge of the valley (Adonido-Brachypodietum in Gnojno and Mogielnica), and on the slopes of flood banks (Tunico-Poetum compresse in Morzyczyn and the Agropyretea intermedio-repentis class in Płatkownica). Sandy grasslands (Diantho-Armerietum in Gnojno and Płatkownica, Sclerantho-Herniarietum glabre in Morzyczyn, Sileno-Festucetum trachyphyllae in Mogielnica) were distributed in a mosaic of meadows at different distances from the river bed. Plant communities were named after Załuski (1995) and Matuszkiewicz (2005) [37-38].

\section{Habitat Complexity}

Measurements of habitat complexity were carried out at each study plot every time the material was collected. We assessed the vegetation cover in four height classes: 1) lower layer $(0-10 \mathrm{~cm}), 2)$ low layer $(10-30 \mathrm{~cm}), 3)$ middle layer $\left(30-50 \mathrm{~cm}\right.$ ), and 4) high layer (above $50 \mathrm{~cm}$ ). A $1 \mathrm{~m}^{2}$ wooden frame was used to measure the vegetation cover in three randomly selected places at each plot. The area of the frame was divided into 16 smaller quadrats to facilitate 
the measurements. The percentage of each vegetation class was estimated in each quadrat and a numerical scale was established: 0 for $0 \%, 1$ for $1-25 \%, 2$ for $26-50 \%$, 3 for $51-75 \%$, and 4 for $76-100 \%$. The mean value was calculated for the whole area of the wooden frame and measurements from three samples were averaged. The resulting figure was the index of vegetation complexity, which can be defined as summed indices of cover degree of vegetation in different height classes. The index was determined for each sample when spider material was collected.

\section{Spider Samples and Data Analyses}

The material was collected in 2007-08 from April to mid-November using pitfall traps. Ten pitfall traps were placed in the ground along a straight line at a distance of two metres on each study plot. Each trap was filled to one-third of its volume with the preservative liquid propylene glycol. In order to reduce the surface tension of the liquid and prevent spiders from escaping, a detergent was added. The pitfall traps were emptied fortnightly. The material was sorted and spiders were identified to the species level. Adult individuals of Alopecosa cuneata and A. pulverulenta found in samples were measured from the front margin of the cephalothorax to the hind end of the abdomen using the Cool View computer program with an accuracy of $0.01 \mu \mathrm{m}$. This value (total length of cephalothorax and abdomen) was defined in our study as body size. Damaged and immature individuals were excluded from the measurements.

Prior to all analyses, the body size of spiders were log-transformed. Based on the conducted measurements, we calculated the mean body size separately for males and females belonging to two analysed spider species for each study plot for each date when material was collected. Each of the resultant values was considered one record.

To assess the effects of vegetation complexity and the type of habitat on spider body sizes, the generalized linear mixed model GLMM was used. Prior to analysis, variables were checked for normal distribution by the Shapiro-Wilk test. The variables "sex" (male vs. female) and "habitat" (mesic meadow, sandy grassland, and xerothermic grassland) were treated as qualitative factors. GLMM was used because data were collected on five study plots, which could be potentially different in terms of some factors (not included in analysis) influencing the body size of two analysed species. Taking into consideration this issue, "place" (one of the five particular places where spiders were collected) was included in analysis as a random variable. Statistical analyses were carried out using the StatSoft software STATISTICA. Results with $\mathrm{p}<0.05$ were considered statistically significant.

\section{Results}

In total, 334 males and 168 females of Alopecosa cuneata and 315 males and 104 females of $A$. pulverulenta were measured. The GLMM analyses showed that the body size of Alopecosa cuneata as well as A. pulverulenta was determined by sex and habitat complexity, whereas the habitat type and place had no influence. Interactions between the analysed variables were not statistically significant (Tables 1-2). Females were larger than males in both analysed species (Fig. 1). The mean body size of A. cuneata, calculated for particular samples, ranged from $5.7 \mathrm{~mm}$ to $8.6 \mathrm{~mm}$ in the case of males and from $7.0 \mathrm{~mm}$ to 10.3 for females. The mean body size of $A$. pulverulenta varied between 5.6 and $7.0 \mathrm{~mm}$ for males and 5.2 and $9.0 \mathrm{~mm}$ for females.

The mean body size of both Alopecosa cuneata and A. pulverulenta increased with the increasing index of habitat complexity (Figs 2-3, respectively).

\section{Discussion}

Among the factors affecting spider assemblages temperature, humidity, and availability of prey [39-41] -

Table 1. Results of GLMM analysis assessing the effect of habitat complexity, habitat type (mesic meadow, sandy grassland, xerothermic grassland), sex, and place on the mean body size of Alopecosa cuneata $(\mathrm{N}=78)$.

\begin{tabular}{|c|c|c|c|}
\hline Variable & $\mathrm{df}$ & $\mathrm{F}$ & $\mathrm{P}$ \\
\hline Habitat complexity & $1,23.08$ & 4.34 & 0.048 \\
\hline Habitat type & $2,6.04$ & 3.15 & 0.116 \\
\hline Sex & $1,0.98$ & 359.18 & 0.036 \\
\hline Place & $4,0.84$ & 5.39 & 0.352 \\
\hline Habitat type x Sex & $2,3.91$ & 0.07 & 0.933 \\
\hline Habitat type x Place & $5,4.15$ & 1.61 & 0.327 \\
\hline Sex x Place & $4,4.50$ & 0.33 & 0.844 \\
\hline Habitat type x Sex x Place & $5,53.00$ & 0.67 & 0.649 \\
\hline
\end{tabular}

Table 2. Results of GLMM analysis assessing the effect of habitat complexity, habitat type (mesic meadow, sandy grassland, xerothermic grassland), sex, and place on the mean body size of Alopecosa pulverulenta $(\mathrm{N}=70)$.

\begin{tabular}{|c|c|c|c|}
\hline Variable & df & $\mathrm{F}$ & $\mathrm{P}$ \\
\hline Habitat complexity & $1,39.15$ & 13.37 & $<0.001$ \\
\hline Habitat type & $2,0.48$ & 2.79 & 0.543 \\
\hline Sex & $1,1.30$ & 64.25 & 0.046 \\
\hline Place & $4,1.81$ & 0.95 & 0.578 \\
\hline Habitat type x Sex & $2,1.15$ & 0.39 & 0.742 \\
\hline Habitat type x Place & $5,3.77$ & 0.57 & 0.724 \\
\hline Sex x Place & $3,5.14$ & 1.85 & 0.254 \\
\hline Habitat type x Sex x Place & $5,46.00$ & 0.50 & 0.778 \\
\hline
\end{tabular}




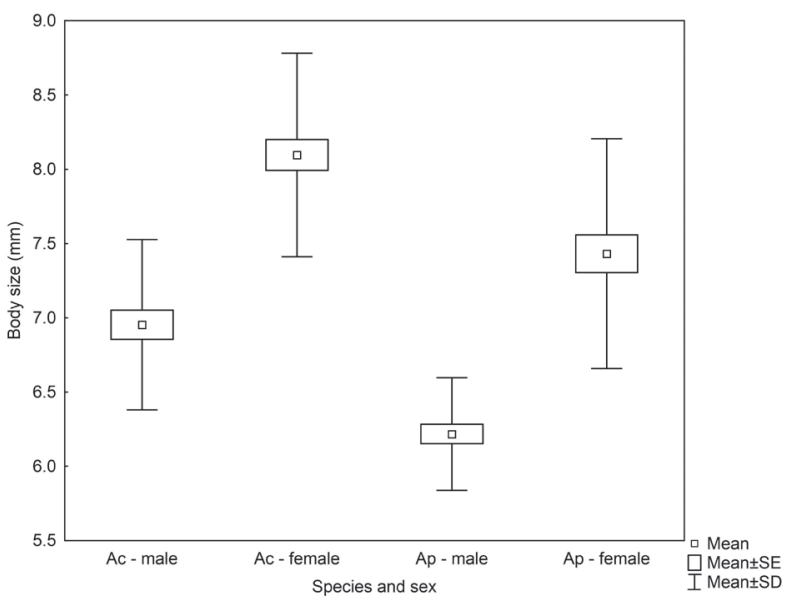

Fig. 1. Comparison of body sizes between sexes of Alopecosa cuneata (Ac) and A. pulverulenta (Ap): mean \pm standard error (SE) and standard deviation (SD).

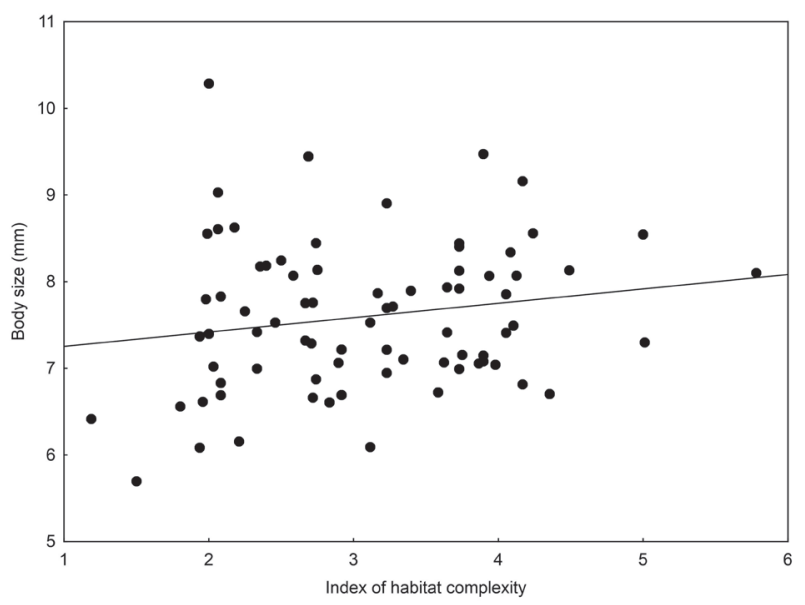

Fig. 2. Relationship between the mean body size of Alopecosa cuneata and the index of habitat complexity.

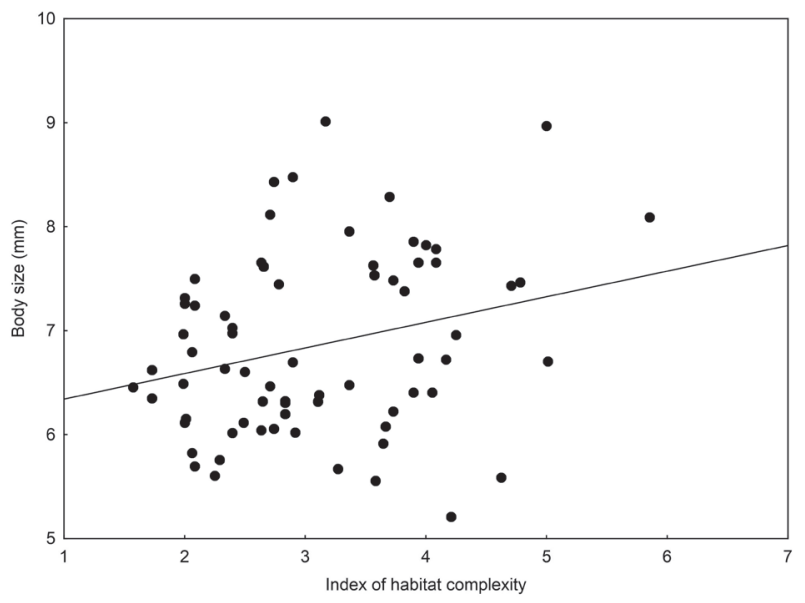

Fig. 3. Relationship between mean body size of Alopecosa pulverulenta and the index of habitat complexity. habitat structure seems to be one of the most important. It determines taxonomic composition, functional diversity, and the abundance of spiders [19, 21, 41-42]. On a scale relevant for spiders, habitat structure is determined mainly by vegetation (or sometimes even by a single plant), which provides spiders with a decent level of humidity, shelter, abundance of prey, and sufficient structures for building webs [22-23, 43]. Structurally more complex habitat increases the number of spiders, spider species, and species diversity [19, 22, 44]. Moreover, field experiments showed that individuals of spiders are larger in such habitats. For example, Halaj et al. (2000) conducted an experiment in which they altered needle density and branching complexity of Douglas-fir canopies and found that the body length of some spider species increased in structurally more complex habitats [27]. Sundberg and Gunnarsson (1994) showed that the density of large (length $\geq 2.5 \mathrm{~mm}$ ) spiders was reduced on branches with a removed portion of needles compared to control branches, while such a relationship was not observed in the case of small spiders [26]. Our results support the findings of these authors. We showed that habitat complexity positively affected the body size of both analysed spider species.

There may be several mechanisms responsible for a larger size of spiders in habitats with a more complex vegetation structure. Organisms of a given species tend to be large because larger individuals, among other things, often have higher reproductive fitness and are better adapted to environmental conditions [45-47]. Some of these conditions, like humidity and shading, may be crucial for spiders' body size. Both are strictly connected with vegetation, which maintains habitat humidity and provides a shadow that protects organisms against water loss. Larger spiders have greater resistance to desiccation compared to small ones, which lose water at a higher rate and thus reducing their survivorship [46, 48]. Therefore, smaller spiders should occur in more humid habitats, which very often means more dense vegetation. Such regularity was observed by Entling et al. (2010) when taking into consideration the mean body size for whole assemblages based on the size of particular species [12]. They revealed that the mean body size of spider species in Europe decreases from warm and dry to cool and moist environments. In our study, conducted at the level of an individual, rather an opposite tendency was observed. Individuals of both $A$. cuneata and A. pulverulenta were larger in more complex and hence probably more humid habitats.

The next factor affecting spider body size is the availability of prey, which is also connected with vegetation and habitat complexity. For example, Halaj et al. (2000) revealed that the abundance of Psocoptera and Collembola, which are typical spiders' prey, was greater in a more complex habitat [27]. Spears and MacMahon (2012) also found more prey items in shrubs with high foliage density compared to low foliage density [39]. Diehl et al. (2013) showed that the order richness of spiders' prey increased with plant diversity 
and vegetation coverage [23]. Size, type, and abundance of potential prey available in habitats may be translated into size of predators, i.e., spiders. The large increase in prey consumption by spiders can reflect the increase in their body size [49]. Moreover, the body size of spiders and their prey are significantly correlated and generally spiders prefer prey smaller than $80-100 \%$ of their own size [50-51]. In general, smaller organisms should prefer habitats with a higher nutritional value of the potential food, because energy costs of obtaining food in sparse habitats exceed nutritional benefits [52-53].

Finally, one of the most important factors affecting body size distribution in animal assemblages is predation. Predators choose their victims selectively and such selection may be based on colour, behaviour, sex, or size [28, 54-57].

The main predators of spiders are birds [28, 58]. Gunnarsson's (1998) field experiment clearly showed that spiders were considerably more abundant on branches protected against birds compared to control branches exposed to bird predation [31]. The importance of birds as a factor affecting the abundance and diversity of spiders (and indirectly the mean body size) was also stressed by Kozlov et al. (2015), who suggested that the impact of birds on spider assemblages was stronger than climate [59]. Unfortunately, studies analysing the impact of bird predation on spiders usually refer only to forests [28].

Birds use their eyesight when searching for prey, thus larger-i.e., more conspicuous - spiders are more exposed to be such prey [29-31]. Both Alopecosa cuneata and A. pulverulenta are strongly exposed to predation because the impact of bird predation on actively preying spiders is much stronger compared to spiders building webs [60]. Sometimes the behaviour that increases the chances of being preyed may be closely related to sex. For example, smaller but roving males of Nephila clavipes suffered a higher mortality rate than larger and sedentary females [61]. On the other hand, a study concerning Pardosa milvina (which belongs, like our model species, to the Lycosidae family) revealed that males had lower survival rate than females, although both sexes exhibited similar levels of activity [62]. In the case of the two analysed spider species, males were more active, which proves their large number compared to females collected in our study. Therefore, they were potentially more exposed to predation; but on the other hand, females were larger, which also increased their chances to be prey. It seems obvious that habitats with more complex structure provide better protection against predators (i.e., birds) for large spiders. As the conducted study revealed, the predation rate is lower in more complex habitat [63] and, moreover, vegetation structure may influence behaviour of birds during foraging [64]. Sundberg and Gunnarsson (1994) found that branches with a removed portion of needles had lower density of large spiders compared to the control branches [26]. This phenomenon was not confirmed in the case of small (below $2.5 \mathrm{~mm}$ ) spiders. Gunnarsson's study (1998) showed that the body size of Pityohyphantes phrygianus (Linyphiidae family) was smaller on branches exposed to bird predation compared to the control, netenclosed branches, but only in spring and not in autumn [31]. The importance of structurally complex habitat as a refuge from predators especially confirmed research on water organisms. For example, the study of Chydorus sphaericus species belonging to Crustacea revealed that larger specimens occurred among macrophytes, and the smallest ones were in the open water zone, which indicated that vegetation was a significant refuge against predators [65].

\section{Conclusions}

The results of our study demonstrated that the body size of spiders inhabiting grasslands was affected by habitat complexity. Individuals from two species, Alopecosa cuneata and $A$. pulverulenta, were larger in a more complex habitat, i.e., with more dense and structurally complicated vegetation. Several mechanisms may determine the body size patterns in spider assemblages, e.g., different microclimatic conditions, availability and size of prey or predation by birds. We suggested that the latter factor is the most crucial one. More complex habitats probably provide better shelter for large spider individuals, which allows them to avoid predators.

\section{Acknowledgements}

We would like to thank the people who contributed to our field and laboratory work, particulary Maria Oleszczuk, Łukasz Nicewicz, Rafał Oskroba, Michał Rzewuski, and Pawel Skorupka. The results of the research carried out under the research theme No. $222 / 05 / \mathrm{S}$ were financed from the science grant granted by the Ministry of Science and Higher Education.

\section{References}

1. MCCUE M.D., SALINAS I., RAMIREZ G., WILDER $\mathrm{S}$. The postabsorptive and postprandial metabolic rates of praying mantises: Comparisons across species, body masses, and meal sizes. J. Insect Physiol. 93-94, 64, 2016.

2. HOLM S., DAVIS R.B., JAVOIŠ J., ÕUNAP E., KAASIK A., MOLLEMAN F., TAMMARU T. A comparative perspective on longevity; the effect of body size dominates over ecology in moths. J. Evol. Biol. 29 (12), 2422, 2016

3. RODGERS G.M., DOWNING B., MORRELL L.J. Prey body size mediates the predation risk associated with being "odd". Behav. Ecol. 26 (1), 242, 2015.

4. HARRISON A., SCANTLEBURY M., MONTGOMERY W.I. Body mass and sex-biased parasitism in wood mice Apodemus sylvaticus. Oikos 119 (7), 1099, 2010.

5. STEEN D.A., MCCLURE C.J.W., SMITH L.L., HALSTEAD B.J., DODD JR C.K., SUTTON W.B., LEE J.R., BAXLEY D.L., HUMPHRIES W.J., GUYER C. The effect of coachwhip presence on body size of North American 
racers suggests competition between these sympatric snakes. J. Zool. 289 (2), 86, 2013.

6. EMMRICH M., PÉDRON S., BRUCET S., WINFIELD I.J., JEPPESEN E., VOLTA P., ARGILLIER C., LAURIDSEN T.L., HOLMGREN K., HESTHAGEN T. MEHNER T. Geographical patterns in the body-sizestructure of European lake fishassemblages along abiotic and biotic gradients. J. Biogeogr. 41 (12), 2221, 2014.

7. PINCHEIRA-DONOSO D., MEIRI S. An intercontinental analysis of climate-driven body size clines in reptiles; no support for patterns, no signals of processes. Evol. Biol. 40 (4), 562, 2013.

8. COETZEE B.W.T., LE ROUX P.C., CHOWN S.L. Scale effects on the body size frequency distributions of African birds; patterns and potential mechanisms. Global Ecol. Biogeogr. 22 (4), 380, 2013.

9. LOPEZ L.C.S., FIGUEIREDO M.S.L., DE AGUIAR FRACASSO M.P., MESQUITA D.O, ANJOS U.U., GRELLE C.E.V. The role of local versus biogeographical processes in influencing diversity and body-size variation in mammal assemblages. Ecol. Evol. 6 (5), 1447, 2016.

10. ULRICH W. Body size distribution of European Hymenoptera. Oikos. 114 (3), 518, 2006.

11. ULRICH W., KOMOSIŃSKI K., ZALEWSKI M. Body size and biomass distributions of carrion visiting beetles: do cities host smaller species? Ecol. Res. 23 (2), 241, 2007.

12. ENTLING W., SCHMIDT-ENTLING M.H., BACHER S., BRANDL R., NENTWIG W. Body size-climate relationships of European spiders. J. Biogeogr. 37 (3), 477, 2010.

13. ULRICH W., FIERA C. Environmental correlates of body size distributions of European springtails (Hexapoda: Collembola). Global Ecol. Biogeogr. 19 (6), 905, 2010.

14. HOMBURG K., SCHULDT A., DREES C., ASSMANN T. Broad-scale geographic patterns in body size and hind wing development of western Palaearctic carabid beetles (Coleoptera: Carabidae). Ecography. 36 (2), 166, 2013.

15. SCRIVEN J.J., WHITEHORN P.R., GOULSON D., TINSLEY M.C. Bergmann's body size rule operates in facultatively endothermic insects: evidence from a complex of cryptic bumblebee species. PLoS One 11 (10), e0163307. doi:10.1371/journal.pone.0163307, 2016.

16. FATTORINI S., SCIOTTI A., TRATZI P., DI GIULIO A. Species distribution, ecology, abundance, body size, and phylogeny originate interrelated rarity patterns at regional scale. J. Zoolog. Syst. Evol. Res. 51 (4), 279, 2013.

17. WARZECHA D., DIEKÖTTER, WOLTERS V., JAUKER F., Intraspecific body size increases with habitat fragmentation in wild bee pollinators. Landscape Ecol. 31 (7), 1449, 2016.

18. WISE D.H. Spiders in ecological webs. Cambridge University Press, Cambridge. 328, 1993.

19. GÓMEZ J.E., LOHMILLER J., JOERN A. Importance of vegetation structure to the assembly of an aerial web-building spider community in North American open grassland. J. Arachnol. 44 (1), 28, 2016.

20. BUTLER V.P., HADDAD C.R. Spider assemblages associated with leaf litter of three tree species in central South Africa (Arachnida: Araneae). Afr. J. Ecol. 49 (3), 301, 2011.

21. GONÇALVES-SOUZA T., ALMEIDA-NETO M., ROMERO G.Q. Bromeliad architectural complexity and vertical distribution predict spider abundance and richness. Austral. Ecology. 36 (4), 476, 2011.

22. MALUMBRES-OLARTE J., VINK C.J., ROSS J.G., CRUICKSHANK R.H., PATERSON A.M. The role of habitat complexity on spider communities in native alpine grasslands of New Zealand. Insect Conserv. Divers. 6 (2), 124, 2013

23. DIEHL E., MADER V.L., WOLTERS V., BIRKHOFER $\mathrm{K}$. Management intensity and vegetation complexity affect web-building spiders and their prey. Oecologia, 173 (2), 579, 2013.

24. DRAPELA T., FRANK T., HEER X., MOSER D., ZALLER J.G. Landscape structure affects activity density, body size and fecundity of Pardosa wolf spiders (Araneae: Lycosidae) in winter oilseed rape. Eur. J. Entomol 108, 609, 2011.

25. GIBB H., MUSCAT D., BINNS M.R., SILVEY C.J., PETERS R.A., WARTON D.I., ANDREW N.R. Responses of foliage-living spider assemblage composition and traits to a climatic gradient in Themeda grasslands. Austral. Ecology. 40 (3), 225, 2015.

26. SUNDBERG I., GUNNARSSON B. Spider abundance in relation to needle density in spruce. J. Arachnol. 22 (3), 190, 1994.

27. HALAJ J., ROSS D.W., MOLDENKE A.R. Importance of habitat structure to the arthropod food-web in Douglas-fir canopies. Oikos. 90 (1), 139, 2000.

28. GUNNARSSON B. Bird predation on spiders: ecological mechanisms and evolutionary consequences. J. Arachnol. 35 (3), 509, 2007.

29. ASKENMO C. VON BRÖMSSEN A., EKMAN J., JANSSON C. Impact of some wintering birds on spider abundance in spruce. Oikos. 28 (1), 90, 1977.

30. GUNNARSSON B. Bird predation and vegetation structure affecting spruce-living arthropods in a temperate forest. J. Anim. Ecol. 65 (3), 389, 1996.

31. GUNNARSSON B. Bird predation as a sex- and size-selective agent of the arboreal spider Pityohyphantes phrygianus. Funct. Ecol. 12 (3), 453, 1998.

32. MCCOY E.D., BELL S.S. Habitat structure: the evolution and diversification of a complex topic. [In:] Bell S.S., McCoy E.D., Mushinsky H.R. (eds) Habitat structure: the physical arrangements of objects in space. Chapman and Hall, London, 3, 1991.

33. NENTWIG W., BLICK T., GLOOR D,. HÄNGGI A., KROPF C. Spiders of Europe. www.araneae.unibe.ch. Version 04.2017.

34. ROZWAŁKA R., SIENKIEWICZ P. Spiders and harvestmen (Arachnida: Araneae, Opiliones) of the Słoneczne Wzgórza Nature Reserve in the Odra Valley. Przegląd Przyrodniczy 25 (3) 31, 2014 [In Polish].

35. HÄNGGI A., STÖCKLI E., NENTWIG W. Habitats of Central European Spiders. Miscellanea Faunistica Helvetiae 4, 4601995.

36. KRONESTEDT T. Separation of two species standing as Alopecosa aculeata (Clerck) by morphological, behavioural and ecological characters, with remarks on related species in the pulverulenta group (Araneae, Lycosidae). Zool. Scr. 19 (2), 203, 1990.

37. ZAŁUSKI T. Meadow communities of Cnidion dubii Bal.Tul 1966 alliance in Poland. Monographiae Botanicae 77, 1, 1995 [In Polish].

38. MATUSZKIEWICZ W. Przewodnik do oznaczania zbiorowisk roślinnych Polski. PWN, Warszawa. p. 540, 2005 [In Polish].

39. SPEARS L.R., MACMAHON J.A. An experimental study of spiders in a shrub-steppe ecosystem: the effects of prey availability and shrub architecture. J. Arachnol. 40 (2), 218, 2012.

40. RŮŽIČKA V., ZACHARDA M. Variation and diversity of spider assembalges along a thermal gradient in scree slopes and adjacent cliffs. Pol. J. Ecol. 58 (2), 361, 2010. 
41. STAŃSKA M., STAŃSKI T., GŁADZKA A., BARTOS M.. Spider assemblages of hummocks and hollows in a primeval alder carr in the Białowieża National Park - effect of vegetation structure and soil humidity. Pol. J. Ecol. 64 (4), 564, 2016.

42. PLATEN R., BERGER G.. The impact of structural and landscape features of set-asides on the spiders (Araneae) of the herb layer. J. Arachnol. 41 (2), 143, 2013.

43. GÓMEZ J.E., LOHMILLER J., JOERN A. Importance of vegetation structure to the assembly of an aerial web-building spider community in North American open grassland. J. Arachnol. 44 (1), 28, 2016.

44. PODGAISKI L.R., RODRIGUES G.G. Spider community responds to litter complexity: insights from a small-scale experiment in an exotic pine stand. Iheringia Série Zoologia. 107, 1, 2017.

45. SHINE R. Ecological causes for the evolution of sexual size dimorphism: a review of the evidence. Q. Rev. Biol. 64 (4), 419, 1989.

46. VINCENT L.S. The natural history of the California Turret Spider Atypoides Riversi (Araneae, Antrodiaetidae): demographics, growth rates, survivorship, and longevity. J Arachnol. 21 (1), 29, 1993.

47. KAPUSTJANSKIJ A., STREINZER M., PAULUS H.F., SPAETHE J. Bigger is better: implications of body size for flight ability under different light conditions and the evolution of alloethism in bumblebees. Funct. Ecol. 21 (6), 1130, 2007.

48. DEVITO J., FORMANOWICZ D.R. The effects of size, sex, and reproductive condition on thermal and desiccation stress in a riparian spider (Pirata sedentarius, Araneae, Lycosidae). J Arachnol. 31 (2), 278, 2003.

49. SHIMAZAKI A., MIYASHITA T. Variable dependence on detrital and grazing food webs by generalist predators: aerial insects and web spiders. Ecography. 28 (4), 485, 2005.

50. NENTWIG W. Epigeic spiders, their potential prey and competitors: relationship between size and frequency. Oecologia 55 (1), 130, 1982.

51. NENTWIG W., WISSEL C. A comparison of prey lengths among spiders. Oecologia. 68 (4), 595, 1986.

52. NOVOTNY V., WILSON M.R. Why are there no small species among xylem-sucking insects? Evol. Ecol. 11 (4), 419, 1997.

53. WARDHAUGH C.W., EDWARDS W., STORK N.E. Body size variation among invertebrates inhabiting different canopy microhabitat: flower visitors are smaller. Ecol. Entomol. 38 (1), 101, 2013.
54. COOK L.M., GRANT B.S., SACCHERI I.J., MALLET J. Selective bird predation on the peppered moth: the last experiment of Michael Majerus. Biol. Lett. 8 (4), 609, 2012.

55. HOY S.R., PETTY S.J., MILLON A., WHITFIELD D.P., MARQUISS M., DAVISON M., LAMBIN X. Age and sexselective predation moderate the overall impact of predators. J. Anim. Ecol. 84 (3), 692, 2015.

56. WORISCHKA S., SCHMIDT S.I., HELLMANN C., WINKELMANN C. Selective predation by benthivorous fish on stream macroinvertebrates - The role of prey traits and prey abundance. Limnologica 52, 41, 2015.

57. GLIWICZ Z.M., SZYMAŃSKA E., WRZOSEK D. Body size distribution in Daphnia populations as an effect of prey selectivity by planktivorous fish. Hydrobiologia. 643 (1), 5, 2010.

58. MESTRE L., GARCIA N., BARRIENTOS J.A., ESPADALER X., PIÑOL J. Bird predation affects diurnal and nocturnal web-building spiders in a Mediterranean citrus grove. Acta Oecol. 47, 74, 2013.

59. KOZLOV M.V., STAŃSKA M., HAJDAMOWICZ I., ZVEREV V., ZVEREVA E.L. Factors shaping latitudinal patterns in communities of arboreal spiders in northern Europe. Ecography 38 (10), 1026, 2015.

60. GUNNARSON B., WIKLANDER K. Foraging mode of spiders affects risk of predation by birds. Biol. J. Linn. Soc. 115 (1), 58, 2015.

61. VOLLRATH F., PARKER G.A. Sexual dimorphism and distorted sex ratios in spiders. Nature. 360, 156, 1992.

62. WALKER S.E., RYPSTRA A.L. Sexual dimorphism and the differential mortality model: is behaviour related to survival? Biol. J. Linn. Soc. 78 (1), 97, 2003.

63. ŠIPOŠ J., KINDLMANN P. Effect of the canopy complexity of trees on the rate of predation of insect. J. App. Entomol. 137 (6), 445, 2013.

64. POWOLNY T., ERAUD C., MASSON J.-D., BRETAGNOLLE V. Vegetation structure and inter-individual distance affect intake rate and foraging efficiency in a granivorous forager, the Eurasian Skylark Alauda arvensis. J. Ornithol. 156 (3), 569, 2015.

65. BASIŃSKA A.M., ANTCZAK M., ŚWIDNICKI K., JASSEY V.E.J., KUCZYŃSKA-KIPPEN N. Habitat type as strongest predictor of the body size distribution of Chydorus sphaericus (O.F. Müller) in small water bodies. Int. Rev. Hydrobiol. 99 (5), 382, 2014. 